\title{
Leiomyosarcoma of soft tissue and pulmonary metastasis, both with osteoclast-like giant cells
}

\author{
T J Matthews, C Fisher
}

\begin{abstract}
A case is described of leiomyosarcoma with osteoclast-like giant cells in soft tissues which metastasised to the lung. The secondary tumour also contained abundant osteoclast-like giant cells, which raises the question of whether they were locally induced or whether they metastasised with the tumour.
\end{abstract}

(F Clin Pathol 1994;47:370-371)

A leiomyosarcoma containing osteoclast-like giant cells arising in the uterus has been reported on several occasions since its initial description, ${ }^{1}$ but it has rarely been described in those tumours originating in the soft tissues. $^{2}$ The malignant giant cell tumour of soft parts (giant cell type of malignant fibrous histiocytoma $(\mathrm{MFH})$ ) is also rare, few cases being reported since the initial description by Guccion and Enzinger in 1972. ${ }^{3} \mathrm{~A}$ case of leiomyosarcoma with osteoclast-like giant cells arising in the thigh is described here, initially considered to be a giant cell variant of $\mathrm{MFH}$.

\section{Case report}

A 71 year old man was referred to the Royal Marsden Hospital, London, for wider exci- sion of a soft tissue tumour from the left thigh. A solid pale mass of $6 \mathrm{~cm}$ in diameter was initially shelled out, and was diagnosed as a giant cell variant of MFH. Sections were reviewed but immunohistochemistry was not available at that time. The resection specimen had several $1 \mathrm{~cm}$ nodules of residual tumour, all of which showed a sarcoma with pleomorphic polygonal and spindle cells, and widely scattered multinucleate giant cells with bland nuclei. These giant cells had the distinct appearance of osteoclast-like cells rather than tumour giant cells. No foci of osteoid, bone, or cartilage were seen.

One year later he developed a pulmonary metastasis which was excised. The specimen was a nodule of lung tissue $2.5 \mathrm{~cm}$ in diameter, covered on one side by visceral pleura. Histologically, a small focus of metastatic tumour was seen, similar in appearance to the primary tumour, with osteoclast-like giant cells in a pleomorphic sarcomatous background (fig 1).

Both primary and secondary tumours showed immunohistochemical positivity for desmin and smooth muscle actin in the spindle cells but not the osteoclast-like giant cells. The giant cells but not the spindle cells were positive for acid phosphatase, by enzyme histochemistry (fig 2).

The patient required resection of recurrent
Department of Histopathology, Royal Brompton Hospital, London

T J Matthews

Department of Histopathology, Royal Marsden Hospital, London C Fisher

Correspondence to: Dr T J Matthews Department of Histopathology, Epsom General Hospital, Dorking Road, Epsom KT18 7EG. Accepted for publication 7 October 1993

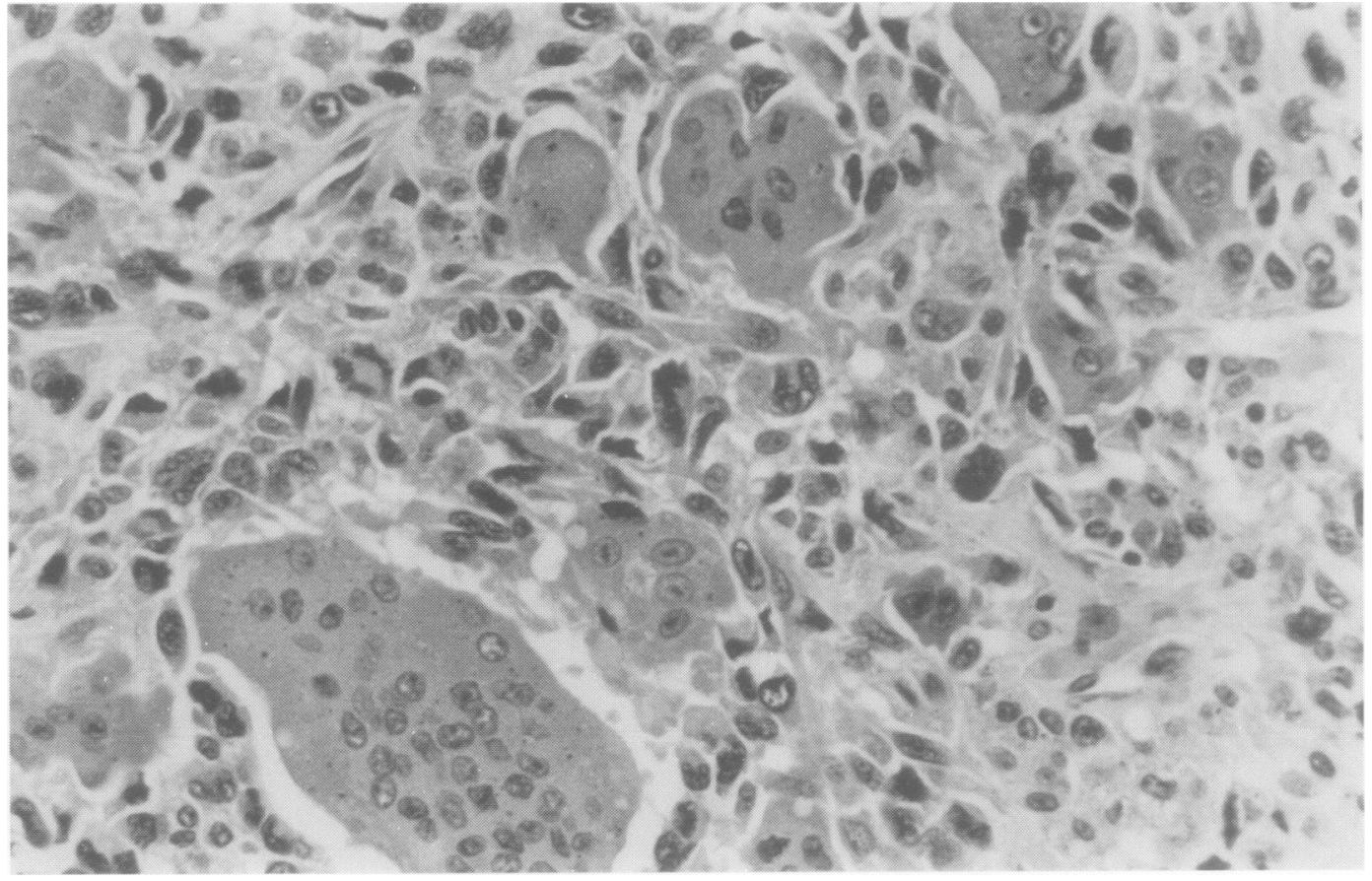

Figure 1 Metastatic sarcoma with prominent osteoclast-like giant cells. 


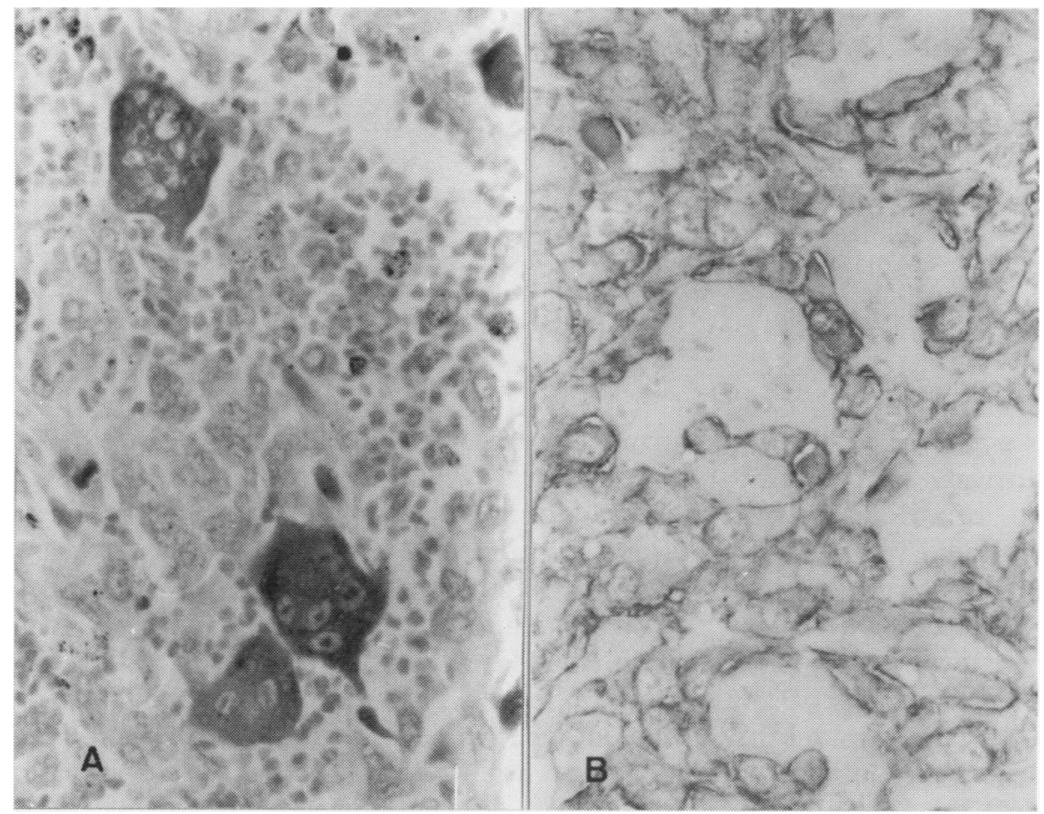

Figure 2 Sarcoma showing positivity for acid phosphatase in the osteoclast-like giant cells $(A)$ and with alpha smooth muscle actin in the mononuclear cells $(B)$.

tumour from his left thigh in January 1992, and further pulmonary metastatectomy in August 1992, both again demonstrating the predominance of the osteoclast-like giant cells. In December 1992 he was alive with no clinical evidence of tumour.

\section{Discussion}

The primary tumour showed morphological and immunohistochemical features of a pleomorphic leiomyosarcoma with the addition of bland multinucleate cells. These resemble osteoclasts on light microscopy and are distinct from the tumour cells.

Four examples of leiomyosarcomas with osteoclast-like giant cells have been reported: three in the uterus ${ }^{145}$ and one in muscle. ${ }^{2}$ In all these tumours the osteoclast-like giant cells were intermingled with the spindle sarcoma cells. They are also recorded as a rare finding in fibrous histocytoma ${ }^{6}$ and malignant melanoma, ${ }^{7}$ and are a prominent component of the malignant giant cell tumour of soft parts (giant cell variant of $\mathrm{MFH}$ ). ${ }^{3}$

The case reported was thought to be a giant cell type of $\mathrm{MFH}$, but was subsequently shown by immunohistochemistry to be a leiomyosarcoma with positive smooth muscle markers. The first reported leiomyosarcoma with osteoclast-like giant cells in the uterus ${ }^{1}$ was only confirmed as such following electron microscopy. It has recently been suggested that many tumours hitherto termed as pleomorphic $\mathrm{MFH}$ may be poorly differentiated examples of other tumour types. ${ }^{8}$ There seems to be no immunohistochemical study of the giant cell variant of $\mathrm{MFH}$, and some examples, if subjected to immunohistochemistry, might prove to be leiomyosarcomas.

The nature and origin of the osteoclast-like giant cells is controversial, both ultrastructural and immunohistochemical studies proving inconclusive. Two reports of leiomyosarcoma with osteoclast-like giant cells considered the giant cells to be a reactive phenomenon, based on their association with haemorrhagic areas and on similarities with histiocytes and giant cells in osteoclastomas. The immunohistochemical results in this case also support the notion that the osteoclastlike giant cells are distinct from the tumour spindle cells, but the observations do not confirm an association with haemorrhagic areas. This is the first reported example of osteoclast-like giant cells in the metastasis of a soft tissue leiomyosarcoma, although two of the uterine tumours were also accompanied by metastases including osteoclast-like giant cells. This raises the further question of whether the osteoclast-like giant cells are locally induced or whether they metastasise with the tumour.

There are insufficient cases of soft tissue leiomyosarcoma to assess whether the presence of osteoclast-like giant cells is prognostically important. From this case their metastatic potential does not seem to be diminished.

1 Darby AJ, Papadaki L, Beilby JOW. An unusual leiomyosarcoma of the uterus containing osteoclast-like giant cells. Cancer 1975;36:495-504.

2 Wilkinson N, Fitzmaurice RJ, Turner PG, Freemont AJ. Leiomyosarcoma with osteoclast-like giant cells. Histopathol 1992;20:446-9.

3 Guccion JG, Enzinger FM. Malignant giant cell tumour of soft parts. An analysis of 32 cases. Cancer 1972; 29:1518-29.

4 Pilon VA, Parikh N, Maccera J. Malignant osteoclast-like giant cell tumour associated with a uterine leiomyosarcoma. Gynecol Oncol 1986;223:381-6.

5 Marshall RJ, Braye SG, Jones DB. Leiomyosarcoma of the uterus with giant cells resembling osteoclasts. Int $\mathcal{f}$ Gynecol Pathol 1986;5:260-8.

6 Enzinger FM, Weiss SW. Soft tissue tumours. 2nd edn. St Louis: CV Mosby, 1988:228.

7 Denton KJ, Stretch J, Athanasou N. Osteoclast-like giant cells in malignant melanoma. Histopathol 1992;20: 179-81.

8 Fletcher CDM. Pleomorphic malignant histiocytoma: fact or fiction? A critical reappraisal based on 159 tumours diagnosed as pleomorphic sarcoma. Am f Surg Pathol 1992;16:213-28. 